\title{
Dynamics of Metabolism in Rana tigrina-A Comparative Biochemical Study between Blood Glucose and Serum Cholesterol during summer and Winter Sleep.
}

\author{
Anupama Kumari ${ }^{1}$, Rajan Verma ${ }^{2}$ and Richa Bharti ${ }^{3}$. \\ ${ }^{1,2}$ R.B.College Road, Dalsingsarai, Samastipur (Bihar). \\ ${ }^{3}$ L.N.M.U. Campus, Nargauna, Darbhanga (Bihar).
}

\begin{abstract}
In the present investigation, effects of successive rising and falling temperature during summer and winter respectively were studied to observe the dynamics of metabolism in Rana tigrina with special reference to a comparative biochemical study observed that the successive rising and falling temperature caused a gradual and significant $(P<0.01)$ rise and fall respectively during the summer and winter sleep in blood glucose level as well as serum cholesterol level in Rana tigrina. The hyperglycemia and hypercholesterolemia might be one of the major impelling causes of 'Aestivation and the hypoglycemia and hypocholesterolemia might be one of the impelling causes of Hibernation'.
\end{abstract}

Key words: Hibernation, Aestivation, Hyperglycemia, Hypercholesterolemia, Dynamics and Metabolism.

\section{Introduction}

The dynamics of Rana tigrina are closely associated with the environmental temperature which is the most important and pervasive physical factors. On the onset of summer and winter its dynamics are adversely affected which led to physiopathological, histopathological and biochemical changes which may evoke some of the impelling causes of hibernation and aestivation dynamics of Rana tigrina.

Some earlier worker like Verma (1984), Govil (1985), Kumar (1992) and Bahadur (1993) have reported the value of blood sugar and serum cholesterol level in Rana tigrina. But no report is available regarding a comparative biochemical study between blood glucose and serum cholesterol during summer and winter sleep. It is in this perspective that the present work has been undertaken.

\section{Material And Methods}

Rana tigrina of both the sexes and standard size and weight were used as an experimental material, which was collected from beneath the earth surface at nearby water reservoirs during summer and winter sleep. In the present investigation the estimation of blood glucose was carried out by adopting Glucose Oxidase / Peroxidase method as described by Varley (1976) whereas the estimation of total serum cholesterol was made by Sackett's method as described by Varley (1976).

\section{Tables}

Table - 1: Showing dynamics of metabolism in Rana tigrina a comparative biochemical study between mean values of Blood Glucose and serum cholesterol during summer sleep.

\begin{tabular}{|l|l|l|l|l|}
\cline { 2 - 5 } \multicolumn{1}{c|}{} & \multicolumn{2}{c|}{ Blood Glucose } & \multicolumn{2}{c|}{ Serum Cholesterol } \\
\hline Months & Male & Female & Male & Female \\
\hline April & 107.1 & 107.6 & 104.6 & 116.0 \\
\hline May & 123.2 & 123.4 & 125.9 & 138.1 \\
\hline June & 152.5 & 153.0 & 157.6 & 167.5 \\
\hline S.E. & $\mathbf{\mathbf { 0 . 7 8 5 }}$ & $\mathbf{\mathbf { 0 . 7 5 6 }}$ & $\mathbf{\mathbf { 1 . 0 5 2 }}$ & $\mathbf{\mathbf { 1 1 0 5 7 }}$ \\
\hline C.D. at 1\% & $\mathbf{- 0 . 0 0 5}$ & $\mathbf{- 0 . 0 0 3}$ & $\mathbf{- 0 . 0 0 8}$ & $\mathbf{- 0 . 0 0 9}$ \\
\hline
\end{tabular}


Table - 2: Showing dynamics of metabolism in Rana tigrina a comparative biochemical study between mean values of Blood Glucose and serum cholesterol during winter sleep.

\begin{tabular}{|l|l|l|l|l|}
\cline { 2 - 5 } \multicolumn{1}{c|}{} & \multicolumn{2}{c|}{ Blood Glucose } & \multicolumn{2}{c|}{ Serum Cholesterol } \\
\hline Months & Male & Female & Male & Female \\
\hline October & 144.7 & 141.9 & 147.4 & 161.3 \\
\hline November & 131.6 & 132.7 & 132.3 & 137.1 \\
\hline December & 102.3 & 100.0 & 101.2 & 111.2 \\
\hline S.E. & $\mathbf{\mathbf { 1 . 5 3 1 }}$ & $\mathbf{\mathbf { 1 . 5 2 3 }}$ & $\mathbf{\mathbf { 1 . 3 3 2 }}$ & $\mathbf{\mathbf { 1 . 3 0 1 }}$ \\
\hline C.D. at 1\% & $\mathbf{- \mathbf { 0 . 0 2 1 }}$ & $\mathbf{- \mathbf { 0 . 0 1 5 }}$ & $\mathbf{- \mathbf { 0 . 0 1 3 }}$ & $\mathbf{- \mathbf { 0 . 0 1 4 }}$ \\
\hline
\end{tabular}

\section{Result And Discussion}

The findings were recorded in Table $1 \&$ Table 2 which showed a comparative study of blood sugar and serum cholesterol in Rana tigrina during summer and winter sleeps. In Table $1 \&$ Table 2 it was observed that the thermal stress during summer sleep caused a gradual and significant $(\mathrm{P}<0.01)$ rise in Blood sugar level and the cold stress during winter sleep caused a gradual and significant $(\mathrm{P}<0.01)$ fall in the same in both the sexes of Rana tigrina. The hyper and hypoglycemia might be attributed to the enhancing and retarding production of epinephrine due to thermal and winter stress in Rana tigrina.

It was clear from the Table $1 \&$ Table 2 that the thermal stress during summer sleep caused a gradual and significant $(\mathrm{P}<0.01)$ rise in Serum Cholesterol and the cold stress during winter sleep caused a gradual and significant $(\mathrm{P}<0.01)$ fall in the same in both the sexes of Rana tigrina. The hyper and hypo cholesterolemia might be attributed to the fact that rising and falling temperature acted as a sort of thermal stress on adrenal gland of frog.

\section{Thesis:}

\section{References}

[1] Bahadur, A. Effect of rising environmental temperature on the metabolism of common frog - $\underline{\text { Rana }} \underline{\text { tigrina }}$ with special reference to serum electrolyte concentration, Ph.D. thesis L.N.M.U. Darbhanga, 1993.

[2] Govil, S.C. Studies on the Changes before hibernation in poikilothermic vertebrate Rana tigrina. Ph.D. thesis, L.N.M.U. Darbhanga, 1985.

[3] Kumar, S. Seasonal variation in the metabolism of the common Indian frog Rana tigrina with special reference to serum electrolyte concentration. Ph.D. thesis, University of Bihar, Muzaffarpur, 1992.

[4] Verma, K.P. Observations on the changes before summer sleep (Aestivation) in common frog - Rana tigrina. Ph.D. thesis, L.M.N.U. Darbhanga, 1984.

Books:

[5] Varley, H. Practical Biochemistry. 4th edition (Indian) Amold Heinemann publishers, (New Delhi, 1976) pp. 88 - 89 \& $309-311$. 